\title{
COOPETITION ENTERPRISES OF AGRI-FOOD SECTOR IN THE REGION UNDERDEVELOPED ECONOMICALLY
}

\author{
Zbigniew Nasalski ${ }^{1}$, PhD \\ ${ }^{1}$ University of Warmia and Mazury in Olsztyn
}

\begin{abstract}
The aim of the study was to identify the most important conditions of coopetition enterprises of agrifood sector in the region underdeveloped economically. The data for the analysis were obtained by means of a diagnostic survey using a questionnaire regarding the status and perspectives of the development of coopetition of business entities from the Braniewo poviat (north-eastern Poland). The agri-food sector is characterized by particularly favourable features that allow the implementation of activities using enterprises' coopetition. Enterprises in the agri-food sector paid a lot of attention to improving cooperation with suppliers and recipients. In the examined region, however, these features did not determine the clear involvement of enterprises in the creation of producer associations and economic clusters. There was limited support of the agri-food sector by the underdeveloped business environment (a situation typical of economically underdeveloped regions). The rational regional policy and the state of development of the business environment in the region can have a significant impact on the development of the coopetition of enterprises. Entities of the agri-food sector deprived of a positive impact of the business environment will have limited opportunities to rationally use coopetition to strengthen their competitive position. Regions underdeveloped economically cannot neglect activities improving the state of the business environment (especially in the area of development of computerization and entities supporting the innovation processes).
\end{abstract}

Key words: coopetition, agri-food sector, region underdeveloped economically.

JEL code: R11.

\section{Introduction and methodology of research}

Coopetition is currently one of the most important types of relations between competitors. This specific relationship is focused on two other jointly appearing: competition and cooperation. Coopetition consists in cooperation of entities that do not cease to be competitors at the same time. By creating economic, organizational and technical relationships, cooperating on innovative projects, they set common strategic goals and often achieve a synergistic effect, inter alia, from the complementarity of resources, organizations and products (Hamel G. et al., 1989; Sulejewicz A., 1997; Cygler J., 2013). Coopetition according to Cygler J. (2009) is characterized by, among others:

- complexity - cooperation and competition are not considered as single relations, but as a set of individual relationships and relations and accompanying processes in strategic terms,

- interdependence - the potentials of the coopetition participants are to a large extent complementary, and the tightening of the cooperation of entities results in a growing dependence of their further actions on these complementary resources,

- dynamism - multifaceted competitive and cooperative relations as well as the need to maintain a proper balance between them, as well as rapidly changing environment, require quick reactions both in the context of individual and joint activities,

- long-term - the complexity of relationships created and strategic goals for coopetition make it necessary to assume long-term benefit

- openness - No limit of entities involved (Cygler J., 2009).

A practical form of coopetition is, for example, economic clusters that are the focus of mutually cooperating enterprises and the entities (institutions) operating in their environment that can help them compete on the market. Grouping of entities into clusters can be based on various parameters, including economic, organizational, geographical and social. In economic theory, the term cluster

\footnotetext{
${ }^{1}$ Corresponding author. Tel.: + 48895234430; E-mail address: zbig@uwm.edu.pl
} 
was disseminated by Porter, who defined it as a geographical focusing of cooperating interrelated enterprises, specialized suppliers, service units, entities operating in related sectors and institutions related to a given activity (eg scientific units, industry organizations) having outstanding competitive success in their areas of activity. The core of the Porter definition is the vertical and horizontal value creation chain. The vertical approach covers the individual stages of the manufacturing process from suppliers to distribution. The horizontal approach refers to industries, sectors using shared distribution channels or dealing in the production of complementary products or services (Porter M.E., 2001; Gorynia M., Jankowska B., 2008).

The benefits of coopetition can be considered in terms of micro-, meso- and macroeconomic. Kladz K. and Kowalski A.M. (2010) include mainly the following elements:

a) in microeconomic terms (from the point of view of an individual enterprise):

- easier access to various types of information,

- greater ability to identify product niches and access to export markets,

- development of human capital,

- increase of production capacity and flexibility of operation thanks to greater resource relocation capabilities,

- reducing uncertainty and risk in business as a result of creating an atmosphere of mutual trust in a changing environment;

b) in terms of mesoeconomic (benefits for the region's economy):

- creating a local culture of innovation and entrepreneurship and economic activation of the region,

- acceleration of knowledge transfer and specialist know-how to the region's economy,

- increasing the competitiveness of the market through the densification of market rivals,

- creating new jobs as a result of dynamic creation of new business entities, including spin-offs,

- concentration of resources and funds for financing business operations, which enables achieving a critical mass for new investments,

- concentration and development of resources of production factors,

- improvement of the region's image;

c) in macroeconomic terms (impact on the national economy):

- impact on the improvement of the economic situation,

- increasing the level of innovation in the economy,

- attracting FDI,

- activation of economic activity, which translates into GDP growth.

The study refers to the agri-food sector, which has particular predispositions to the practical use of coopetition because it is characterized by functional interdependencies indicating a significant cooperial potential, which could be effectively used with proper mesoeconomic policy in the process of competing. This potential stems from the following dependencies in the sector.

1) Agricultural farms provide a raw material base for food processing. The quantity of raw material in individual regions of the country depends on their structure and productivity. Agricultural farms also shape the quality of raw materials, which are processed in the processing industry. There are practical tools to stimulate the quality of the raw material by the processing industry. It can be done, among others by providing agricultural holdings with knowledge, genetic material, feed, veterinary services etc. 
2) Agricultural farms constitute an important stage in shaping the sanitary and hygienic correctness, they are a link preceding the food industry, which should be interested on maintaining high standards in this respect.

3) The possibilities of selling raw materials by agricultural farms depend on the market efficiency of processing enterprises.

4) The competitive position of processing enterprises depends on ensuring systematic supplies to the market dependent on the stability supply of agri raw material from farms.

5) The perception of food producers by consumers is more and more often made through the prism of the region of obtaining raw materials (eg with well-known environmental values) and the production system in farms supplying (e.g. organic) (Nasalski Z., 2008).

Despite these features, the practical implementation of coopetition in the agri-food sector is limited, therefore the aim of the study was to identify the most important determinants of the coopetition of enterprises in the agri-food sector in the underdeveloped region. This can be the basis for optimizing regional development strategies and actions stimulating competitiveness in the field of economic policy in regions with a significant share of the agri-food sector. The study concerns the economically underdeveloped region because very often regions with a traditional economic structure, with prevailing agriculture and food processing, without an efficient business environment usually have limited prospects of economic development. The study refers to one of the least economically developed regions of Poland - the north-western part of the Warmia and Mazury Voivodeship (the Braniewo poviat). The unemployment rate in this region is one of the highest in the country. A significant share in the social structure is long-term unemployed and professionally inactive. Entrepreneurs from the Braniewo poviat are limited in scope to activities focused on innovation and the growth of competitive position.

The adopted mesoeconomic perspective is increasingly being considered in the analysis of economic problems (Gorynia M., 1995; Gorynia M., Jankowska B., 2008). This is mainly due to the application aspects - the macroeconomic approach in some circumstances is too general to solve the problem relating to certain specific sectors of the economy, e.g. individual industries or regions, microeconomic approach, however, most often focuses on the problems of individual economic entities. Modern economy requires more and more often the use of new instruments of competition, e.g. strategic partnership, integrated supply chains, coopetition, synergies, cooperation within proinnovation programs, etc. These activities usually include not individual entities but their groups (e.g. in the region). Data for analysis was obtained by means of a diagnostic survey using a questionnaire concerning the condition and perspectives of the development of coopetition of business entities from the Braniewo poviat. They made it possible to identify the opinions of business owners regarding this issue, among others on the subject of: the importance of the factors that most stimulate the development of enterprises, the influence of environmental institutions on the development of local entrepreneurship in the opinion of entrepreneurs, the most important actions implemented to improve the competitiveness of enterprises. In the questionnaire, the surveyed entrepreneurs determined the occurrence or impact of individual factors on the development of their companies and the economic development of the Braniewo poviat. The method used in the research allowed respondents on a scale of 1 point (which meant a factor with a low impact) to 5 points (a factor with a strong impact) to indicate the importance of particular factors in the functioning and development of their enterprises. The internal conditions of the surveyed units and the impact of factors related to the operations of enterprises were also determined. In the Braniewo poviat, there 
were in 2017 about 3.1 thou. enterprises, research questionnaires were sent to a representative group of 220 entities. After verifying the completeness of the obtained data, 199 questionnaires were used in the analysis. The structure of the studied group was to a large extent convergent with the actual structure of enterprises located in the Braniewo poviat.

The research hypothesis assumed that the agri-food sector alone would not be able to smoothly integrate enterprises. In order for the coopetition processes to be able to be used in practice, a significant share of the business and institutional environment as well as advanced informatization processes integrating the behaviour of entities is also needed. In a region with low business environment potential there is often a gap in integration processes.

\section{Research results and discussion}

The results of the research presented in a synthetic way diagnosed important features of enterprises in the agri-food sector, occurring in business practice indicating high coopetition potential (as compared to other enterprises from the studied region). On the other hand, this potential did not have a clear impact on the creation of business organizations based on coopetition. When comparing the measures implemented to improve the competitiveness of enterprises in the agri-food sector against the background of all surveyed enterprises, it should be noted that the most important was raising the quality of production (services provided), improving work organization and diversifying products (Figure 1). Raising the quality of production usually requires access to the results of innovative research and modern technologies. In the food economy it often requires cooperation consisting, for example, in the coordination of the characteristics of agricultural raw materials sold by many producers to one processor, among others through the flow of knowledge, the supply of genetic material, feed, veterinary services, etc. Enterprises in the agri-food sector appreciated more clearly the improvement of work organization, and lay slightly less emphasis on the diversification of products. In addition, enterprises in the agri-food sector have very clearly paid attention to the development of their own distribution network and product specialization, and most importantly, they attached great importance to improving cooperation with suppliers and customers. According to Jankowska B. (2012), cooperation with the environment (especially with suppliers and recipients) in creative clusters is crucial for their development. The entities from the agri-food sector were very clearly (against the background of all researched enterprises) emphasizing the search for cheaper sources of supply. Companies from the analysed sector, however, paid less attention to employ better specialists and systematic employee training. It should also be pointed out that the enterprises of the agri-food sector are more determined to introduce products to new markets and to enter current markets with new products. What is worrying is the limited scope of IT activities supporting management decisions, actions aimed at reducing production costs and low involvement in establishing business associations and clusters. Firlej K. (2008) research also indicates that there is a large relationship between the competitive advantage of enterprises in the agri-food sector and the place of business activity, which may have a positive impact, inter alia, on on the level of mutual trust and enhance the effects of coopetition.

The researched enterprises declared different knowledge and use of coopetition in business practice, including attitude to participate in economic clusters (but also in producer groups, associations, etc.). According to the declarative level of coopetition, the factors that most stimulate the development of the surveyed enterprises were determined (Figure 2). Enterprises showing a high level of coopetition were more positive towards the majority of factors that could be stimulants for 
their development. In particular, these enterprises recognize the importance of such factors as: prodevelopment tax system and entrepreneurship-friendly administrative system, low employment costs, relatively small market risk, access to investment areas and absorptive local market.

improving the quality of production / services

improvement of work organization

diversification of products / services developing your own distribution network product specialization

improving cooperation with recipients reducing production costs searching for cheaper sources of supply employing better specialists improving cooperation with suppliers systematic employee training proecological activities active motivating employees introduction of existing products to new markets entering new products into existing markets implementation of advanced management. reduction of employment entering new products into new markets application of information systems supporting simplifying organizational structures creating associations / producer groups...

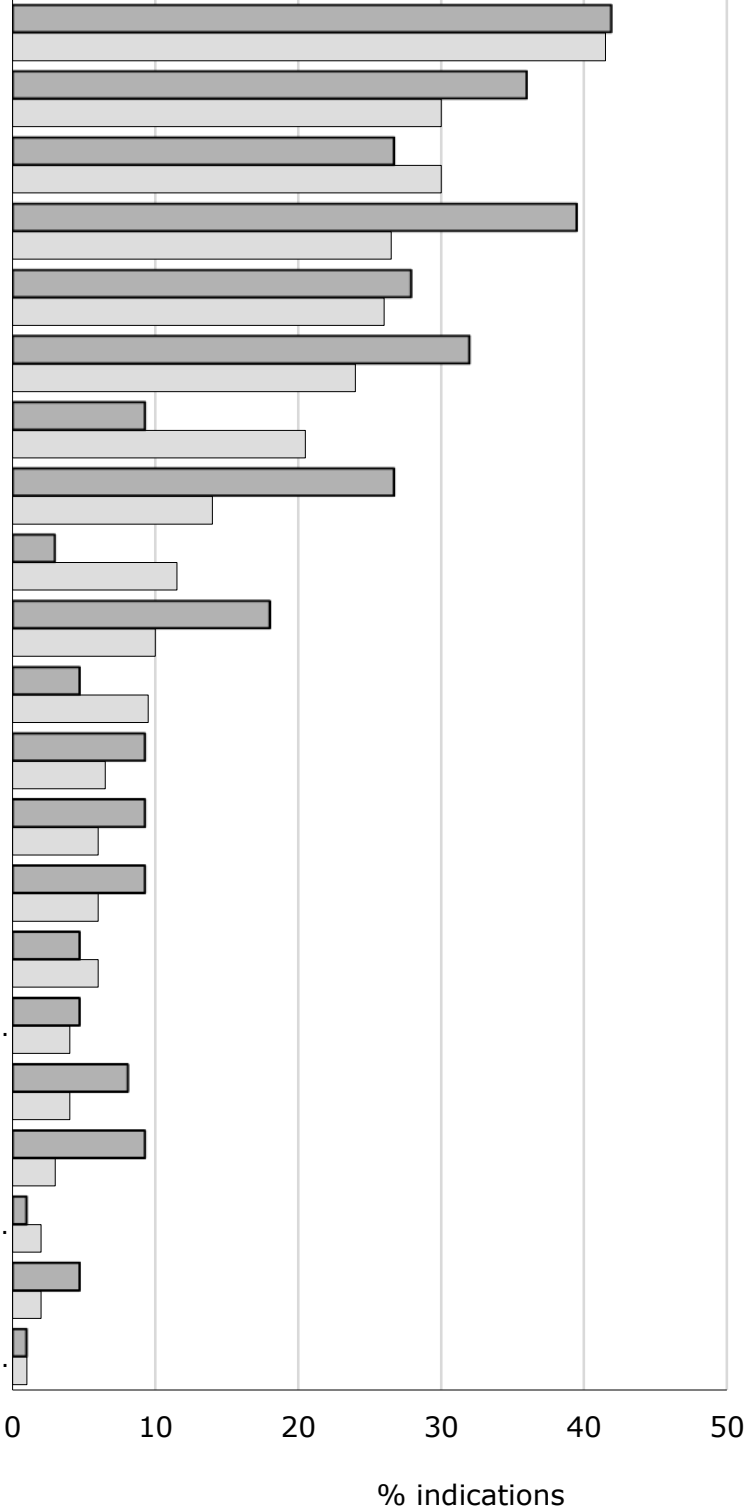

口enterprises in the agri-food sector $\square$ total enterprises

Source: author's research

Fig. 1. The most important activities implemented to improve the competitiveness of the surveyed enterprises, with particular emphasis on the agri-food sector ( $\%$ indications)

Enterprises declaring a low level of coopetition in their economic activities particularly clearly pointed to the good situation in the industry and the company's potential. These entities were generally less optimistic about using most of the factors of entrepreneurship development. 


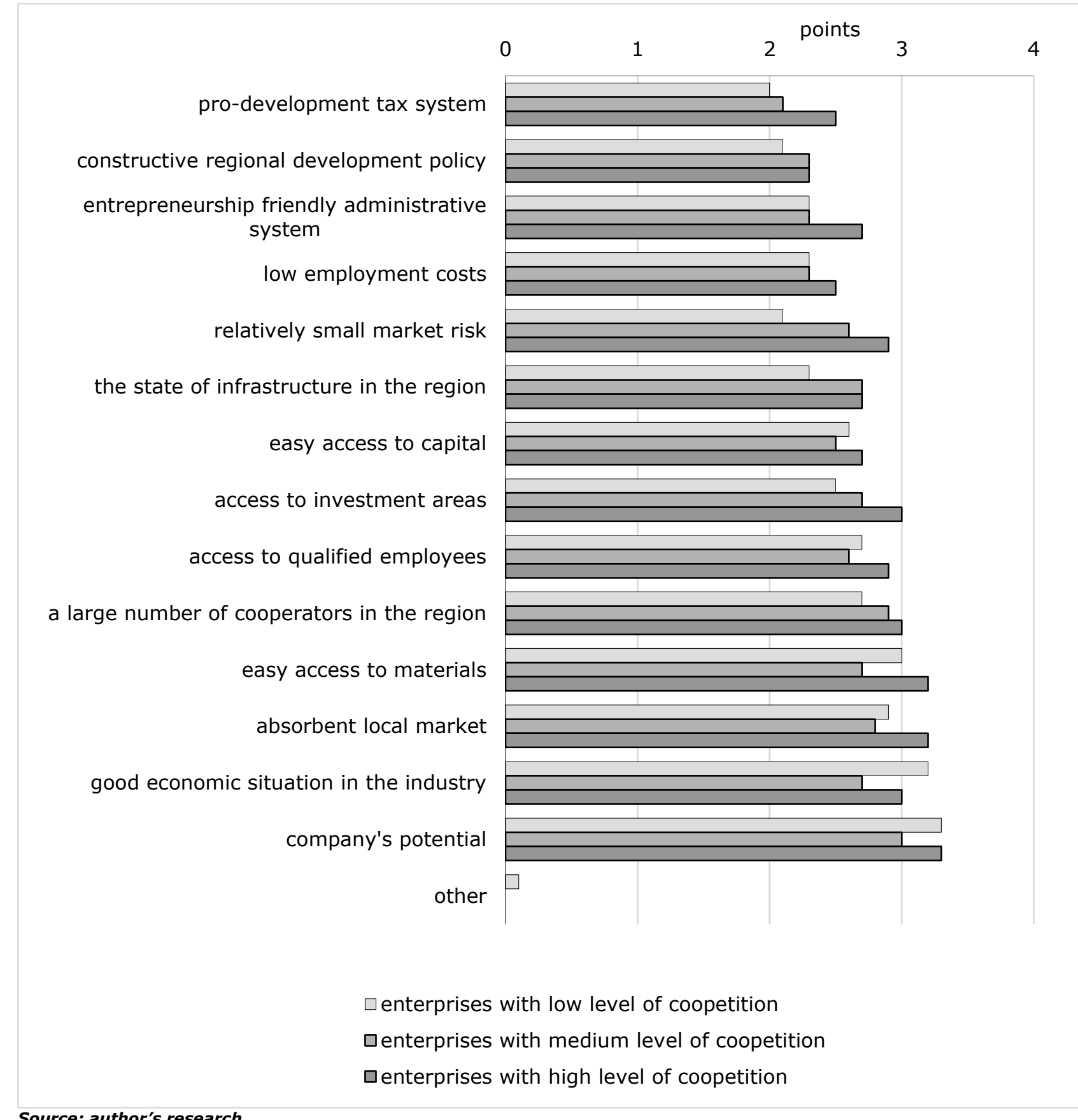

Source: author's research

Fig. 2. The importance of the factors that most stimulate the development of the surveyed enterprises with varying degrees of coopetition ( 1 - small significance, 5 - very important) (average points)

When assessing the impact of the institution on the development of local coopetition, entrepreneurs from the Braniewo poviat, the strongest impact was indicated by the functioning of existing economic clusters, entrepreneurs' organizations and voivodship self-government authorities (Figure 3). The relatively lowest recognition of entrepreneurs was directed at employee organizations (unions) and community authorities. Research by Figiel Sz. et al. (2012) indicate that cluster organizations in the agri-food sector are often based on an eclectic set of cooperating entities, which according to the authors is not always a beneficial one. Skawinska E. and Zalewski R. (2009) and Kowalski A.M. (2013) emphasize the special role of innovative institutions in the development of coopetition. 


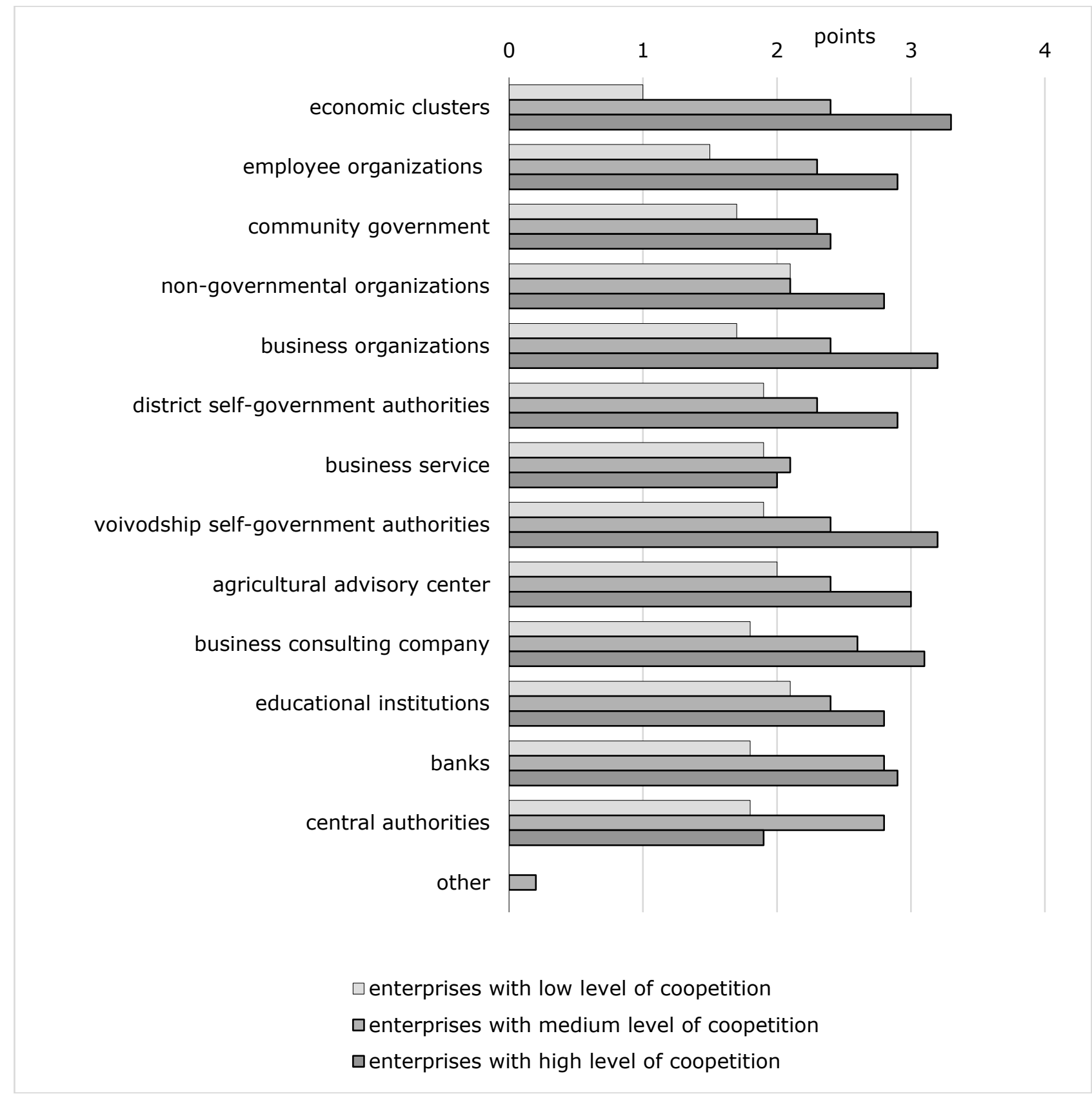

Source: author's research

Fig. 3. Impact of the institution on the development of local entrepreneurship in the opinion of the surveyed entrepreneurs with different degrees of coopetition ( 1 - small, 5 - very large) (average points)

The researches enterprises showing a high level of coopetition were relatively the most positive attitude towards the majority of business environment entities, especially those with local impact. They assessed the significance of central authorities' actions in the context of the development of coopetition relatively less well.

\section{Conclusions, proposals, recommendations}

1) The agri-food sector is characterized by particularly favourable features that allow the implementation of economic activities with the use of coopetition also in economically underdeveloped regions. This is due to from the attention of the entities of this sector to the quality of production, activity in the search for opportunities to develop their own distribution network and product specialization, determination of enterprises to launch products into new markets and enter current markets with new products. These enterprises attached great 
importance to improving cooperation with suppliers and recipients. In the region under consideration, however, these features did not determine a clear commitment to the creation of producer associations and economic clusters. A coopetition gap was identified, consisting of limited support for the agri-food sector (with significant coopetition potential) through a relatively weaker business environment.

2) Regional policy and the state of the business environment in the region have a significant impact on the chances of developing the coopetition of enterprises. Entities exhibiting a high level of coopetition were relatively positive towards using most of the factors that could be stimulants of their development and to cooperate with business environment institutions having an impact on the development of local coopetition. Entities of the agri-food sector deprived of a positive impact of the business environment will have limited opportunities to rationally use coopetition to strengthen their competitive position. Underdeveloped regions cannot neglect activities that improve the state of the business environment (especially in the area of development of computerization and entities supporting innovative activities).

\section{Bibliography}

1. Cygler, J. (2009). Kooperencja przedsiebiorstw. Czynniki sektorowe i korporacyjne (Coopetition of enterprises. Sector and corporate factors). Oficyna Wydawnicza SGH, Warszawa, pp. 19-22.

2. Cygler, J. (2013). Korzysci kooperencji - oczekiwania i efekty (Benefits of coopetition - expectations and effects). Organizacja i Kierowanie 5, pp. 59-75.

3. Figiel, Sz., Kuberska, D., Kufel, J. (2012). Klastry i inicjatywy klastrowe w polskim sektorze rolnozywnosciowym (Clusters and cluster initiatives in the Polish agri-food sector). IERiGZ, Warszawa, pp. 121126.

4. Firlej, K. (2008). Rozwoj przemyslu rolno-spozywczego w sektorze agrobiznesu i jego determinanty (The development of the agri-food industry in the agribusiness sector and its determinants). Wydawnictwo Uniwersytetu Ekonomicznego w Krakowie, Krakow, pp. 173-185.

5. Gorynia, M. (1995) Teoria i polityka regulacji mezosystemow gospodarczych a transformacja postsocjalistycznej gospodarki polskiej (Theory and policy of regulating economic mesosystems and the transformation of the post-socialist Polish economy). Wydawnictwo Akademii Ekonomicznej w Poznaniu, Poznan, pp. 34-41.

6. Gorynia, M., Jankowska, B. (2008). Klastry a miedzynarodowa konkurencyjnosc i internacjonalizacja przedsiebiorstwa (Clusters and international competitiveness and internationalization of the company). Difin, Warszawa, pp. 30-50.

7. Hamel, G., Doz, Y.L., Prahalad, C.K. (1989). Collaborate with Your Competitors and Win. Harvard Business Review 67/1, pp. 133-139.

8. Jankowska, B. (2012). Koopetycja w klastrach kreatywnych. Przyczynek do teorii regulacji w gospodarce rynkowej (Coopetition in creative clusters. A contribution to the theory of regulation in the market economy). Wydawnictwo Uniwersytetu Ekonomicznego w Poznaniu, Poznan, pp. 241-302.

9. Kladz, K., Kowalski, A.M. (2010). Stan rozwoju klastrow w Polsce. [w:] Polska. Raport o konkurencyjnosci 2010. Klastry przemyslowe a przewagi konkurencyjne (Cluster development status in Poland. [in:] Poland. Report on competitiveness 2010. Industrial clusters and competitive advantages). Instytut Gospodarki Swiatowej, SGH w Warszawie, Warszawa, pp. 266- 267.

10. Kowalski, A.M. (2013). Znaczenie klastrow dla innowacyjnosci gospodarki w Polsce (The importance of clusters for innovation in the economy in Poland). Oficyna Wydawnicza SGH, Warszawa, pp. 99-122.

11. Nasalski, Z. 2008. Structural gap in the links among agribusiness enterprises. Olsztyn Economic Journal 3(1), pp. 103-113.

12. Porter, M.E. (2001). Porter o konkurencji (Porter about competition). PWE, Warszawa.

13.Skawinska, E., Zalewski, R. (2009). Klastry biznesowe w rozwoju konkurencyjnosci i innowacyjnosci regionow. Swiat - Europa - Polska (Business clusters in the development of competitiveness and innovation of regions. World - Europe - Poland). Polskie Wydawnictwo Ekonomiczne, Warszawa, pp. 277-279.

14. Sulejewicz, A. (1997). Partnerstwo strategiczne: modelowanie wspolpracy przedsiebiorstw (Strategic partnership: modeling of cooperation of enterprises). Oficyna Wydawnicza SGH, Warszawa, pp. 64-75. 